DOI: http://dx.doi.org/10.21123/bsj.2016.13.3.0547

\title{
Synthesis and study of biological activity of some new Imidazole derivatives
}

\author{
Abdul Jabar Kh. Atia* Mohammed fraj Al-Marjani** \\ Muayad Abbood Qaban*
}

*Department of Chemistry, College of Science, Al- Mustansiriya University.

**Department of Biology, College of Science, Al- Mustansiriya University.

Received 26/5 /2015

Accepted 16/9/2015

(1) 99

This work is licensed under a Creative Commons Attribution-NonCommercialNoDerivatives 4.0 International Licens

\begin{abstract}
:
In this work ester derivatives were synthesized by the reaction of imidazole derivatives (C1) with ethylchloroacetate in ethanol and $\mathrm{NaOH}$ to give the corresponding (C2). While compound (C3) acetohydrazide was synthesized by the reaction of ester derivatives $(\mathrm{C} 2)$ with hydrazine hydrat in ethanol. Compound (C3) from the reaction with different aromatic aldehydes in absolute ethanol gave the Schiff's bases $(\mathrm{C} 4, \mathrm{C} 5)$. The product compounds were characterized by FT-IR, U.V and ${ }^{1} \mathrm{HNMR}$ spectra and the biological activities were studied as antibacterial.
\end{abstract}

Key words: acetohydrazide, Schiff's bases, Imidazole.

\section{Introduction:}

In recent years, heterocyclic compounds had been received considerable attention due to their pharmacological and pesticidal importance [1-9]. The simplest of five membered heterocyclic compounds are pyrrole, furan and thiophene, each of which contains a single hetero atom [10]. Benzothiophene [11] a class of heterocyclic compounds containing a benzene ring fused with five membered aromatic ring made up of one sulfur as heteroatom with formula $\mathrm{C}_{8} \mathrm{H}_{6} \mathrm{~S}$. Benzothiophene undergoes electrophillic aromatic substitution at $\mathrm{C}$ 2 and C-3 equally [12] .

\section{Materials and Methods:}

Infrared spectra were recorded on (FTIR-8400s Fouriero Trans Form

infrared Spectrophotometer Shimadzu). UV Spectra were recorded on UVVisible spectrophotometer (VARIAN) UV-1650PC. ${ }^{1} \mathrm{H}-\mathrm{NMR}$ spectra (Burker DMX -500 NMR spectrophotometer) were recorded on ultra shield $300 \mathrm{MHZ}$ in Jordan, with tetra methyl silane as internal standerd and DMSO as a solvent. Melting points were determined in a(Gallen kamp MFB-600- Melting point apparatus) melting point apparatus with sample contained in open capillary glass tube in a electrically heated metal block apparatus ,and were uncorrected. All chemicalls were supplied from BDH, Merck, Fluka and used without further purification. 
Synthesis of 1-amino-2-(3-chlorobenzo [b] thiophen-2-yl) -4-(4-(N,Ndimethylami-no) benzylidene)-1Himidazol-5(4H)-one(C1)

Hydrazine hydrate $(99 \%, 10 \mathrm{ml})$ was added to a mixture of compound (2-(3chlorobenzo[b]thiophen-2-yl)-4-

(4(dimethylamino)benzylidene)oxazol$5(4 \mathrm{H})$-one) $(0.01 \mathrm{~mol})$ in dry benzene (5 $\mathrm{ml})$. The reaction mixture was refluxed for $20 \mathrm{hrs}$ after cooling the sold product was obtained the desired compound. The physical properties are listed in Table(1) [13] .

Synthesis of ethyl (2-(3-chlorobenzo [b]thiophen-2-yl)-4-(4-(N,N-dimethylamino) benzylidene) -5-oxo-4,5dihydro -1H-imidazol-1-yl)amino) acetate(C2)

The corresponding compound (C1) (3.94 g, $0.01 \mathrm{~mol}$ ) was refluxed with an equivalent amount $(0.04 \mathrm{~g}, 0.01 \mathrm{~mol})$ of $\mathrm{NaOH}$ in absolute ethanol for 2 hrs. Then, ethyl chloroacetate (1.36 g, 0.01 mol) was added and refluxed for an additional $5 \mathrm{hrs}$. After evaporating the solvent under reduced pressure, a solid was appeared and washed with distilled water and recrystallized from ethanol to afford the desired compound [14] .

Synthesis of 2-(2-(3-chlorobenzo[b] thiophen-2-yl) -4-(4- (N,N-dimethylamino) benzylidene)-5-oxo-4,5-dihydro-1H-imidazol-1-yl)amino)acetohydrazide (C3)

A mixture of compound (C2) $(4.80 \mathrm{~g}$ , 0.01mol) and hydrazine hydrate $(99 \%$, $0.32 \mathrm{~g}, 0.01 \mathrm{~mole})$ in ethanol $(25 \mathrm{ml})$ was refluxed for $8 \mathrm{hrs}$. Upon cooling the solution a solid appeared, and recrystallized from ethanol [15].

Synthesis of N'-(4-bromobenzylidene) -2-(2- (3-chlorob- enzo[b] thiophen-2yl) -4-(Arylidene) -5-oxo-4,5- dihydro1H-imidazol-1-yl)amino) acetohydrazide(C4,C5)

The corresponding aryl aldehyde (0.01 mol) was added to a stirred solution of compound (C3) (4.76 g, $0.01 \mathrm{~mol})$ in absolute ethanol $(20 \mathrm{ml})$ and the mixture was refluxed for $8 \mathrm{hrs}$. After cooling, the mixture was filtered and the solid recrystallized from ethanol to afford the desired compound. The physical properties were listed in Table(1) [16] .

Table (1): Physical properties of compounds (C1 - C5)

\begin{tabular}{|c|c|c|c|c|}
\hline Comp. No & Compound structure & Colour & Yield \% & M.P \\
\hline $\mathrm{C} 1$ & & Deep red & 86 & $138-140$ \\
\hline $\mathrm{C} 2$ & & brown & 87 & 209-211 \\
\hline $\mathrm{C} 3$ & & orange & 73 & 202-204 \\
\hline $\mathrm{C} 4$ & & yellow & 80 & $213-215$ \\
\hline C5 & & $\begin{array}{l}\text { Green- } \\
\text { yellow }\end{array}$ & 67 & 205-207 \\
\hline
\end{tabular}




\section{Results and Discussion:}

For the synthesis of the targeted compounds ( $\mathrm{C} 1-\mathrm{C} 5)$, the reaction sequences are outlined in scheme (1):

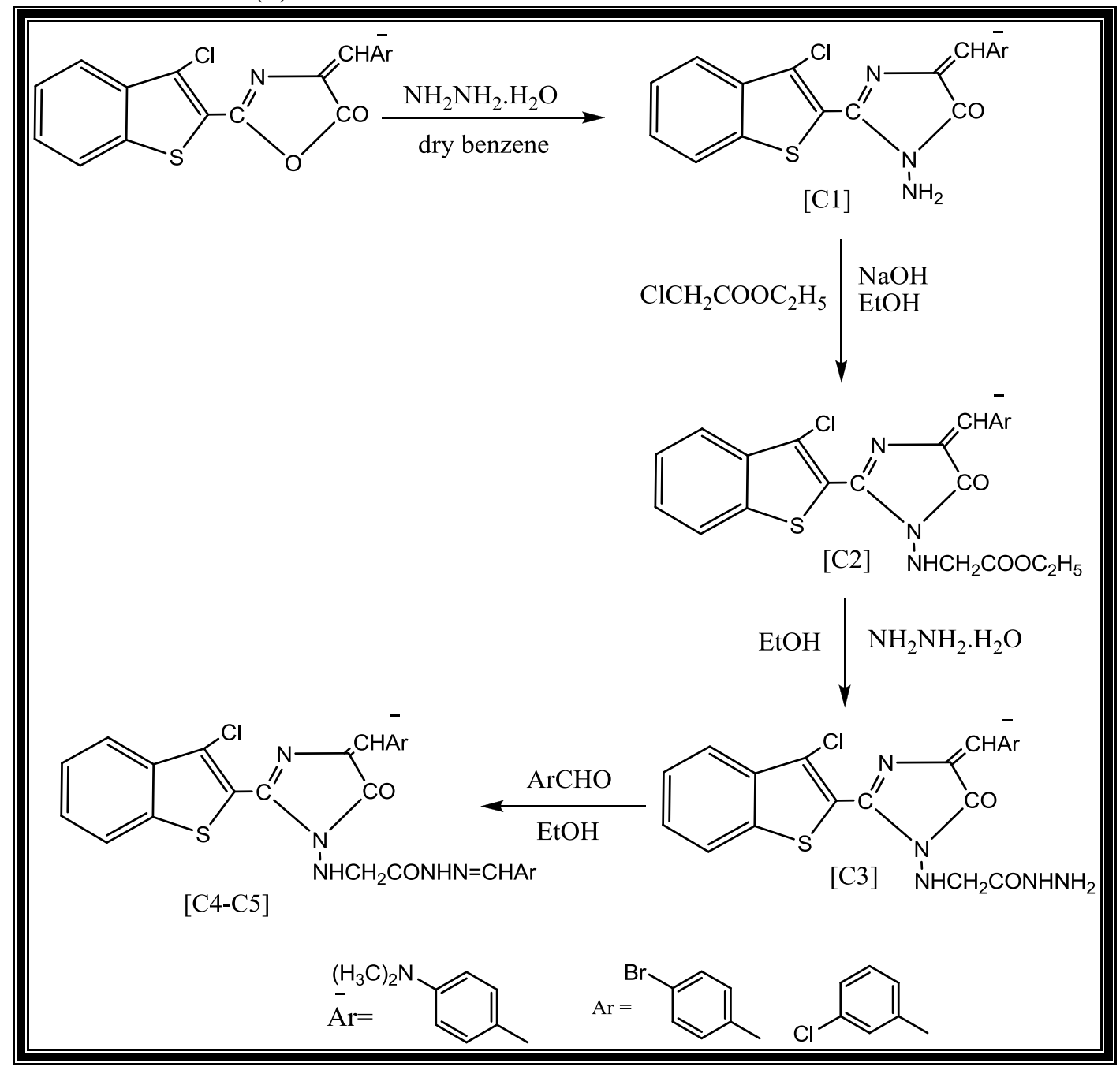

Scheme (1): Synthesis imidazole derivatives

Synthesis of 1-amino-2-(3-chlorobenzo[b] thiophen-yl) -4-(Arylidene) 1H-imidazol -5(4H)-one(C1)

This compound was synthesized when hydrazine hydrate in dry benzene was refluxed with oxazole to give (C1). Titled compound was indicated by the appearance of the stretching vibration bands at(3348) $\mathrm{cm}^{-1}$ to $\mathrm{NH}_{2}$ groups and decreasing of stretching vibration bands at $(1664) \mathrm{cm}^{-1}$ to carbonyl group .The product $(\mathrm{C} 1)$ was confirmed by FT-IR and U.V. spectra. FT-IR spectrum(Fig.1), Table (2) shows the stretching vibration bands at(3348-3229) $\mathrm{cm}^{-1}$ due to stretching vibration (asymmetric and symmetric)for $\left(\mathrm{NH}_{2}\right)$ group ,band at (3117) $\mathrm{cm}^{-1}$ due to for $(=\mathrm{CH})$ group ,band at $(3030) \mathrm{cm}^{-1}$ due to aromatic $(\mathrm{C}-\mathrm{H})$, band at $(1664) \mathrm{cm}^{-1}$ due to $(\mathrm{C}=\mathrm{O})$ group, band at $(1627) \mathrm{cm}^{-1}$ due to $(\mathrm{C}=\mathrm{N})$ group and band at $(1599-1525)$ $\mathrm{cm}^{-1}$ due to for aromatic $(\mathrm{C}=\mathrm{C})$. UV spectrum of compound (C1) shows intense maxima at $(269 \mathrm{~nm})$ and $(327$ $\mathrm{nm})$ due to $\pi \rightarrow \pi^{*}$ and $\mathrm{n} \rightarrow \pi^{*}$ electronic transition, respectively. 


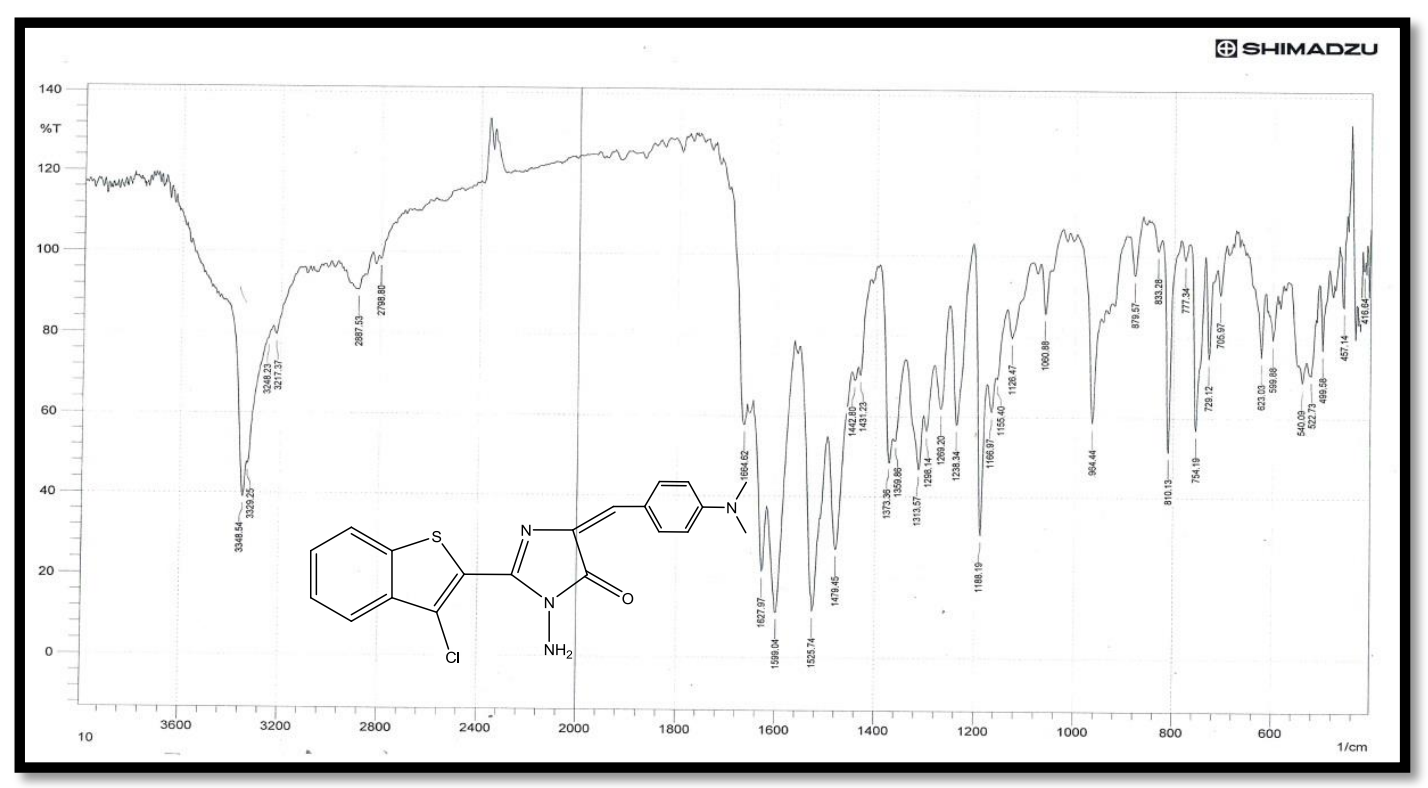

Fig. 1: The FT-IR spectrum of compound (C1)

Synthesis of ethyl 2-(2-(3-chlorobenzo[b]thiophen-2-yl)-4-(4-(dimethylamino) benzylidene)-5-oxo-4,5-dihydro-1H-imidazol-1-ylamino)acetate

(C2)

Imidazole derivative was synthesized by reaction of compound (C1) with ethylchloroacetate in ethanol to give the corresponding (C2). The formation of titled compounds were indicated by the appearance of the $\mathrm{NH}$ stretching vibration band, two carbonyl stretching vibration bands and disappearance of the stretching vibration bands (asymmetric and symmetric) for $\left(\mathrm{NH}_{2}\right)$ group. The structure of $(\mathrm{C} 2)$ was confirmed by FT-IR, U.V and ${ }^{1}$ HNMR spectrum . FT-IR spectrum (Fig .2) ,Table (2) showed the stretching vibration band at $(3340) \mathrm{cm}^{-1}$ due to $(\mathrm{NH})$ group, band at(3064) $\mathrm{cm}^{-1}$ due to aromatic (C-H) , band at (2926-2868) $\mathrm{cm}^{-1}$ due to aliphatic $(\mathrm{CH})$, band at $(1683) \mathrm{cm}^{-1}$ due to $(\mathrm{C}=\mathrm{O})$, band at (1635) $\mathrm{cm}^{-1}$ due to $(\mathrm{C}=\mathrm{N})$ and band at $(1599-1516) \mathrm{cm}^{-1}$ due to aromatic $(\mathrm{C}=\mathrm{C})$
group.UV spectrum of compound (C2) shows intense maximum at $(258 \mathrm{~nm})$ and ( $327 \mathrm{~nm}$ ) due to $\pi \rightarrow \pi^{*}$ and $n \rightarrow \pi^{*}$ electronic transition, respectively.The ${ }^{1} \mathrm{H}-\mathrm{NMR}$ of compound (C2) (Fig.3), Table(2) shows the following signals:

- Doublet at(7.89-7.91) ppm due to aromatic proton near $\mathrm{N}\left(\mathrm{CH}_{3}\right)_{2}$. - Doublet at(7.76-7.79) ppm due to aromatic proton far $\mathrm{N}\left(\mathrm{CH}_{3}\right)_{2}$. - Multiplet at (7.34-7.65) ppm due to aromatic proton for benzo[b] thiophene ring.

- Singlet at (6.53) ppm assigned to $(=\mathrm{CH})$ proton.

- Singlet at (5.83) ppm due to $\left(\mathrm{N}-\mathrm{CH}_{2}\right)$ proton.

- Quartet at (5.14) ppm due to $\left(\mathrm{OCH}_{2}\right)$ proton.

- Singlet at(4.44) ppm due to (NH) proton.

- Singlet at(2.96) ppm due to aliphatic $\left[\mathrm{N}\left(\mathrm{CH}_{3}\right)_{2}\right]$ proton.

Triplet (0.9) ppm due to aliphatic $\left(\mathrm{CH}_{3}\right)$ proton. 


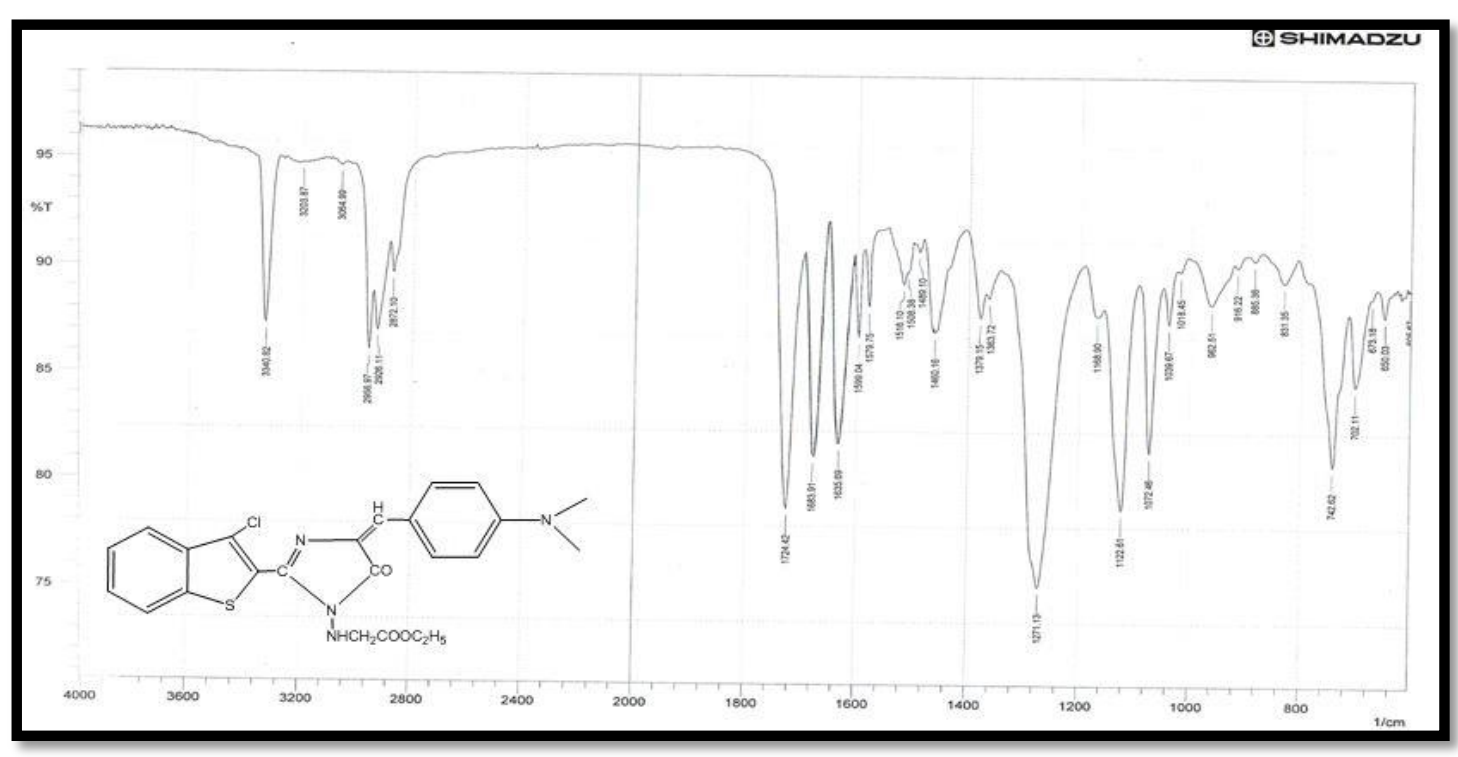

Fig. 2: The FT-IR spectrum of compound (C2)

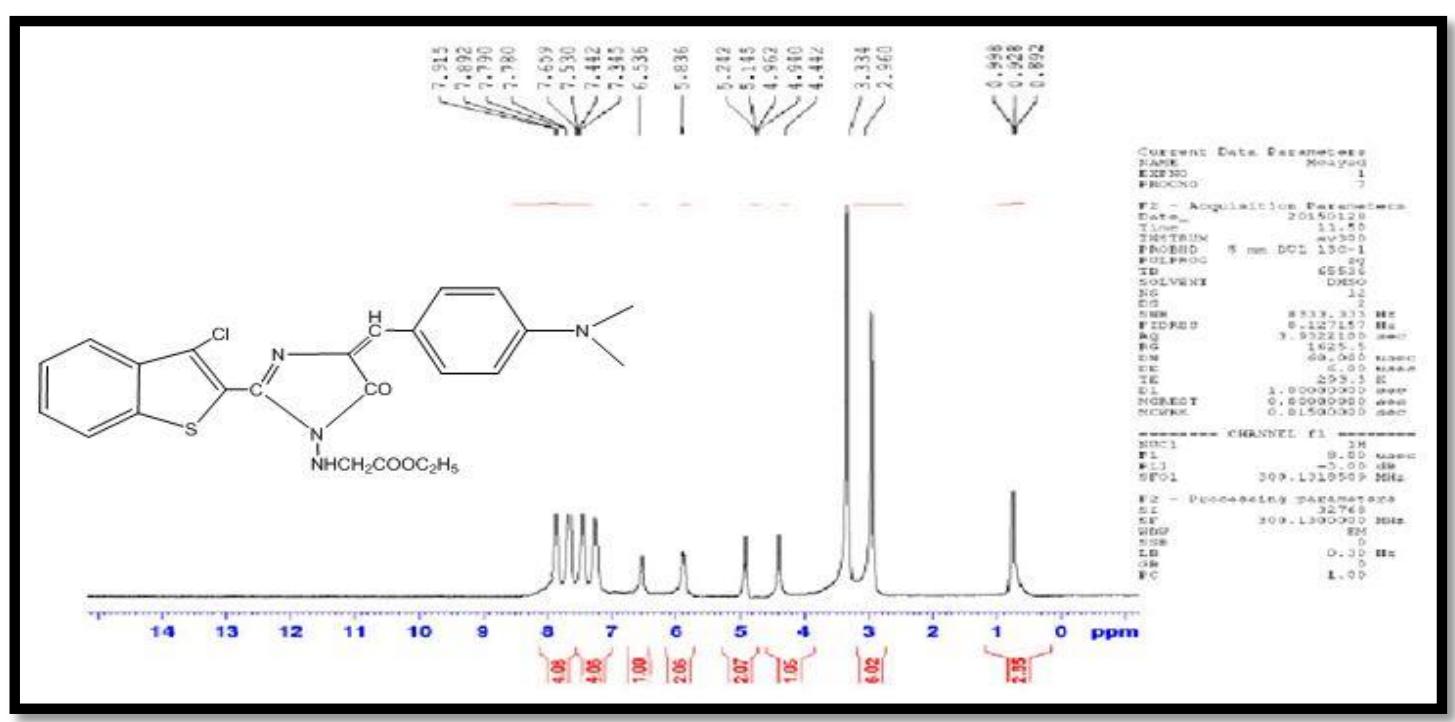

Fig. 3: The ${ }^{1} \mathrm{H}$-NMR spectrum of compound (C2)

Synthesis of 2-(2-(3-chlorobenzo [b] thiophen-2-yl)-4-(4-(dimethylamino) benzylidene)-5-oxo-4,5-dihydro-1Himidazol-1-ylamino) acetohydrazide (C3)

Hydrazide was synthesized by the reaction of ester (C2) with hydrazine hydrate in ethanol to give the corresponding (C3). The formation of title compounds was indicated by the appearance of the two NH stretching vibration bands, amidic carbonyl stretching vibration bands and appearance of the $\mathrm{NH}_{2}$ stretching vibration bands . The structure of (C3) was confirmed by FT-IR and U.V spectra. FT-IR spectrum (Fig .4), Table (2) shows the stretching vibration bands at $(3385-3350) \mathrm{cm}^{-1}$ due to $\left(\mathrm{NH}_{2}\right)$ groups, band at(3290-3180) $\mathrm{cm}^{-1}$ due to(NH) band at (3024) $\mathrm{cm}^{-1}$ due to aromatic (C-H), band at(2990-2835) $\mathrm{cm}^{-}$ ${ }^{1}$ due to aliphatic $(\mathrm{CH})$, band at (1681$1668) \mathrm{cm}^{-1}$ due to $(\mathrm{C}=\mathrm{O})$, band at $(1626)$ $\mathrm{cm}^{-1}$ due to $(\mathrm{C}=\mathrm{N})$ and band at $(1589$ 1510) $\mathrm{cm}^{-1}$ due to aromatic $(\mathrm{C}=\mathrm{C})$ group.UV spectrum of compound (C3) shows intense maxima at $(238 \mathrm{~nm})$ and ( $276 \mathrm{~nm}$ ) due to $\pi \rightarrow \pi^{*}$ and $\mathrm{n} \rightarrow \pi^{*}$ electronic transition, respectively. 


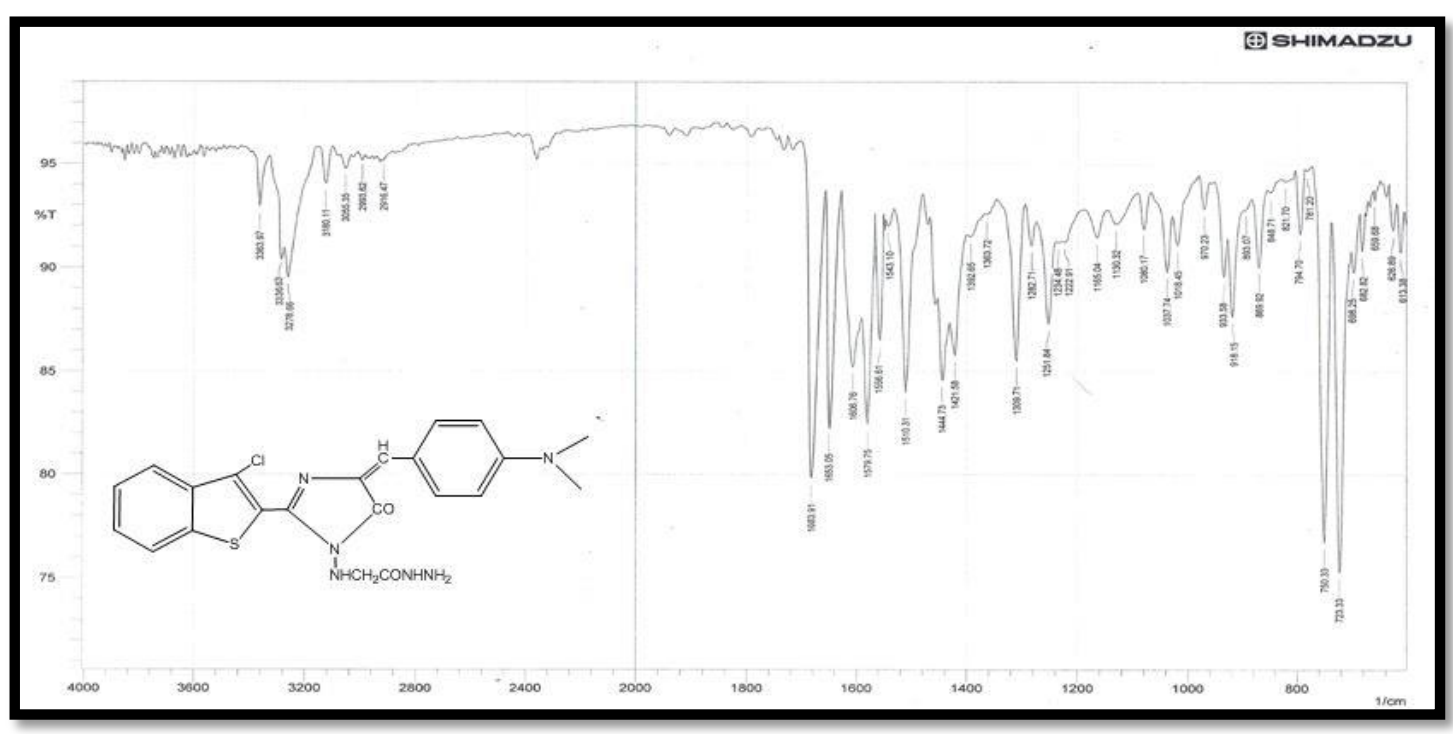

Fig. 4: The FT-IR spectrum of compound (C3)

Synthesis of N'-(4bromobenzylidene)-2-(2-(3-chlorobenzo[b]thiophen-2-yl)-4-(Arylidene)5-oxo-4,5-dihydro-1H-imidazol-1ylamino)acetohydrazide $(\mathrm{C4}, \mathrm{C5})$

Compound (C3) undergoes the character condensation reaction with different aromatic aldehyde in absolute ethanol to give the Schiff's bases (C4C5) The formation of these Schiff's bases was indicated by the disappearance of the $\mathrm{NH}_{2}$ stretching vibration bands. The structure of (C4) was confirmed by FT-IR and U.V spectra . FT-IR spectrum (Fig .5), Table (2)shows the stretching vibration band at
(3265-3235) $\mathrm{cm}^{-1}$ due to(NH), band at (3169) $\mathrm{cm}^{-1}$ due to $(\mathrm{N}=\mathrm{CH})$, band at (3095) $\mathrm{cm}^{-1}$ due to $(=\mathrm{CH})$, band at (3057) $\mathrm{cm}^{-1}$ due to aromatic $(\mathrm{C}-\mathrm{H})$, band at (2935-2870) $\mathrm{cm}^{-1}$ due to aliphatic $(\mathrm{CH})$, band at(1688-1660) $\mathrm{cm}^{-1}$ due to $(\mathrm{C}=\mathrm{O})$, band at (1618) $\mathrm{cm}^{-1}$ due to $(\mathrm{C}=\mathrm{N})$, band at $(1593-1560) \mathrm{cm}^{-1}$ due to aromatic $(\mathrm{C}=\mathrm{C})$ group and band at (858) $\mathrm{cm}^{-1}$ due to for (C-Br) group. Spectrum also shows other characteristic bands in Table (2). UV spectrum of compound (C4) shows intense maxima at ( $255 \mathrm{~nm}$ ) and (314 nm) due to $\pi \rightarrow \pi^{*}$ and $\mathrm{n} \rightarrow \pi^{*}$ electronic transition, respectively.

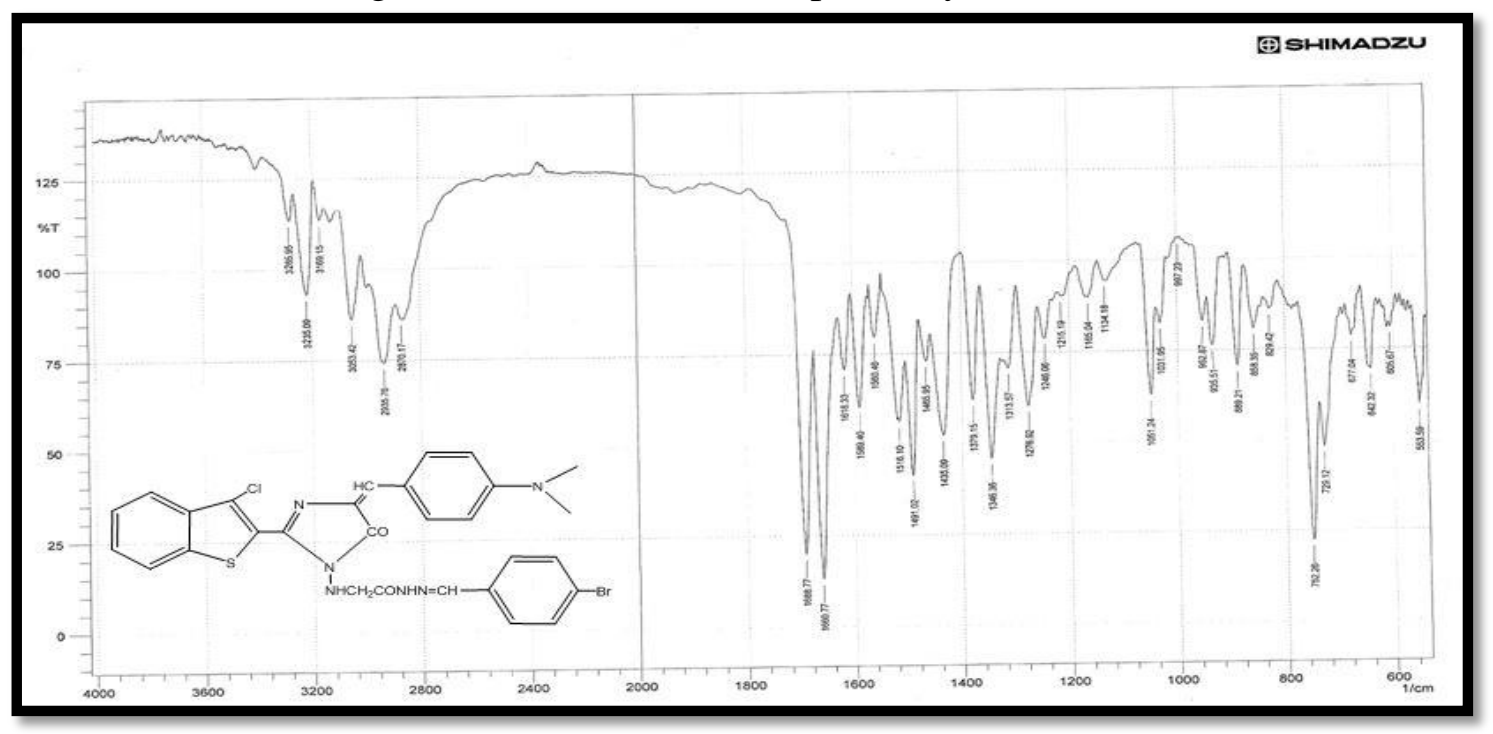

Fig. 5: The FT-IR spectrum of compound (C4) 
Table (2): IR and ${ }^{1} \mathrm{H}-\mathrm{NMR}$ spectral data for compounds (C1 - C5)

\begin{tabular}{|c|c|c|c|c|c|c|c|c|}
\hline \multirow{2}{*}{$\begin{array}{c}\text { Comp. } \\
\text { No }\end{array}$} & \multicolumn{7}{|c|}{ Characteristic IR bands $\mathrm{Cm}^{-1}$} & \multirow{2}{*}{$\begin{array}{c}\mathrm{H}^{1}-\mathrm{NMR} \backslash \mathrm{ppm} \\
(\mathrm{DMSO} 300 \mathrm{MHz})\end{array}$} \\
\hline & $\mathrm{NH}$ & $\begin{array}{c}\mathrm{CH} \\
\text { arom }\end{array}$ & $\mathrm{CH}$ aliph & $\mathrm{C}=\mathrm{O}$ & $\mathrm{C}=\mathrm{N}$ & $\begin{array}{l}\mathrm{C}=\mathrm{C} \\
\text { arom }\end{array}$ & other & \\
\hline $\mathrm{C} 1$ & & 3030 & $\begin{array}{r}2980- \\
2887 \\
\end{array}$ & 1664 & 1627 & $\begin{array}{l}1599- \\
1525 \\
\end{array}$ & $\begin{array}{c}3348-3329 \\
\left(\mathrm{NH}_{2}\right)\end{array}$ & \\
\hline $\mathrm{C} 2$ & 3340 & 3064 & $\begin{array}{l}2926- \\
2872\end{array}$ & $\begin{array}{l}1724- \\
1683\end{array}$ & 1635 & $\begin{array}{l}1599- \\
1516\end{array}$ & & $\begin{array}{c}\mathrm{d}(7.89-7.91) \text { near } \mathrm{N}\left(\mathrm{CH}_{3}\right)_{2}, \\
\mathrm{~d}(7.76-7.79) \text { far } \mathrm{N}\left(\mathrm{CH}_{3}\right)_{2}, \\
\mathrm{~m}(7.34-7.65) \text { benzo }[\mathrm{b}] \\
\text { thiophene ring. } \\
\mathrm{s}(6.53)(=\mathrm{CH}) \\
\mathrm{s}(5.83)\left(\mathrm{N}^{2} \mathrm{CH}_{2}\right) \\
\mathrm{q}(5.14)\left(\mathrm{OCH}_{2}\right), \\
\mathrm{s}(4.44)\left(\mathrm{NH}^{2}\right), \mathrm{s}(2.96) \text { aliphatic } \\
{\left[\mathrm{N}^{2}\left(\mathrm{CH}_{3}\right)_{2}\right], \quad \mathrm{t}(0.9)} \\
\text { aliphatic }\left(\mathrm{CH}_{3}\right) \text { proton. } \\
\end{array}$ \\
\hline $\mathrm{C} 3$ & 3290-3189 & 3024 & $\begin{array}{l}2990- \\
2835 \\
\end{array}$ & $\begin{array}{c}1681- \\
1668 \\
\end{array}$ & 1626 & $\begin{array}{l}1589- \\
1510 \\
\end{array}$ & $\begin{array}{c}(3385-3350) \\
\text { for }\left(\mathrm{NH}_{2)}\right. \\
\end{array}$ & \\
\hline $\mathrm{C} 4$ & $3265-3235$ & 3057 & $\begin{array}{l}2935- \\
2870\end{array}$ & $\begin{array}{l}1688- \\
1660\end{array}$ & 1618 & $\begin{array}{l}1593- \\
1516\end{array}$ & $\begin{array}{c}(3169) \\
(\mathrm{N}=\mathrm{CH}),(858) \\
\text { for }(\mathrm{C}-\mathrm{Br})\end{array}$ & \\
\hline C5 & 3363-3224 & 3055 & $\begin{array}{l}2947- \\
2868\end{array}$ & $\begin{array}{l}1680- \\
1662\end{array}$ & 1626 & $\begin{array}{l}1591- \\
1514\end{array}$ & $\begin{array}{c}(3171) \\
(\mathrm{N}=\mathrm{CH}) \\
(777) \text { for }(\mathrm{C}- \\
\mathrm{Cl})\end{array}$ & \\
\hline
\end{tabular}

\section{Determination of antibacterial activity:}

The effect of (C1-C5) on different microorganisms was studied and compared between them .However ,the results can seen in Table (3) ,(4),(5),(6), which they show that the concentrations $\quad(10000,5000,1000,500)$ $\mu \mathrm{g} / \mathrm{ml}$ exhibit very effective inhibition towards the three types of bacteria , Pseudomonas aeruginosa and E.coli ,gram negative bacteria and $S$. aureus ,gram positive bacteria. In experiment, we found Broad-spectrum antimicrobial activity toward S.aureus a maximum of $1-2 \mathrm{~cm}$ in (C1- C5) compounds, E.coli and $P$. aeruginosa and about $1-2 \mathrm{~cm}$ in (C1- C5) compounds.

Table(3) The effect of(C1-C5) (10000) $\mu \mathrm{g} / \mathrm{ml}$ represented by inhibition zone (mm) against different bacterial species.

\begin{tabular}{|c|c|c|c|}
\hline \multirow{2}{*}{ Comp.No } & \multicolumn{3}{|c|}{ Bacterial species } \\
\cline { 2 - 4 } & S. aureus & E.coli & P. aeruginosa \\
\hline C1 & +++ & +++ & ++ \\
\hline C2 & ++ & ++ & ++ \\
\hline C3 & ++ & ++ & ++ \\
\hline C4 & +++ & +++ & +++ \\
\hline C4 & ++ & ++ & +++ \\
\hline
\end{tabular}

Table(4) The effect of(C1-C5) (5000) $\mu \mathrm{g} / \mathrm{ml}$ represented by inhibition zone (mm) against different bacterial species.

\begin{tabular}{|c|c|c|c|}
\hline \multirow{2}{*}{ Comp.No } & \multicolumn{3}{|c|}{ Bacterial species } \\
\cline { 2 - 4 } & S. aureus & E.coli & P. aeruginosa \\
\hline C1 & +++ & +++ & ++ \\
\hline C2 & +++ & +++ & +++ \\
\hline C 3 & ++ & ++ & ++ \\
\hline C4 & ++ & +++ & ++ \\
\hline C5 & +++ & +++ & +++ \\
\hline
\end{tabular}

Table(5) The effect of(C1-C5) (1000) $\mu \mathrm{g} / \mathrm{ml}$ represented by inhibition zone (mm) against different bacterial species.

\begin{tabular}{|c|c|c|c|}
\hline \multirow{2}{*}{ Comp.No } & \multicolumn{3}{|c|}{ Bacterial species } \\
\cline { 2 - 4 } & S. aureus & E.coli & P. aeruginosa \\
\hline C1 & +++ & +++ & ++ \\
\hline C2 & +++ & +++ & +++ \\
\hline C3 & ++ & ++ & ++ \\
\hline C 4 & ++ & +++ & ++ \\
\hline C5 & +++ & +++ & +++ \\
\hline
\end{tabular}

Table(6) The effect of(C1-C5) (500) $\mu \mathrm{g} / \mathrm{ml}$ represented by inhibition zone (mm) against different bacterial species.

\begin{tabular}{|c|c|c|c|}
\hline \multirow{2}{*}{ Comp.No } & \multicolumn{3}{|c|}{ Bacterial species } \\
\cline { 2 - 4 } & S. aureus & E.coli & P. aeruginosa \\
\hline C1 & +++ & +++ & ++ \\
\hline C2 & +++ & +++ & +++ \\
\hline C3 & +++ & +++ & +++ \\
\hline C4 & ++ & +++ & ++ \\
\hline C5 & +++ & +++ & +++ \\
\hline
\end{tabular}

(-) No inhibition zone

(+) Inhibition zone between (7-10) $\mathrm{mm}$.

(++) Inhibition zone between (10-15) $\mathrm{mm}$.

$(+++)$ Inhibition zone between $(15-20) \mathrm{mm}$. 


\section{References:}

[1] Liu, X. H.; Tan, C. X. and Weng, J. Q. 2011. Phase transfer-catalyzed, One-pot synthesis of some novel npyrimidinyl -n'- nicotinyl thiourea derivatives. Phosphorus, Sulfur Silicon Relat.Elem,186(3):552-557.

[2] Su, N. N.; Li, Y.; Yu, S. J. ; Zhang, X.; Liu, X. H. and Zhao, W. G. 2013.Microwave-assisted synthesis of some novel 1,2,3-triazoles by click chemistry, and their biological activity. Res. Chem. Intermed, 39(2): 759-766.

[3] Liu, X. H.; Pan, L.; Tan, C. X.; Weng, J. Q.; Wang, B. L. and Li, Z. M. 2011. Synth- esis, crystal structure, bioactivity and DFT calculation of new oxime ester derivatives containing cyclopropane moiety. Pestic. Biochem. Physiol, 101(3):143-147.

[4] Liu, X. H.; Pan, L.; Ma, Y.; Weng, J. Q.; Tan, C. X.; Li, Y. H.; Shi, Y. X.; Li, B. J.; Li, Z. M. and Zhang, Y. G. 2011. Design, synthesis, biological activities, and 3D-QSAR of new N,N'-diacylhydrazines containing2(2,4-dichlorophenoxy) propane moiety. Chem. Biol. Drug Des, 78(4): 689-694.

[5] Chen, P. Q.; Tan, C. X.; Weng, J. Q. and Liu, X. H. 2012. Synthesis, Structure and DFT calculation of chlorimuron-ethyl. Asian. J. Chem, 24(6):2808-2810.

[6] Liu, X. H.; Weng, J. Q. and Tan, C. X. 2013. Synthesis, crystal structure, and fungicidal activity of 5-(4cyclopropyl-5-((3-fluorobenzyl)thio)4H-1,2,4-triazol-3-yl)-4-methyl1,2,3-thiadiazole. J. Chem, 2013:doi:10.1155/2013/306361.

[7] Tong, J. Y.; Shi, Y. X.; Liu, X. H.; Sun, N. B. and Li, B. J. 2012. Synthesis and fungicidal activity of 1,2,4-triazole derivatives containing 2-fluorophenyl moiety. Chin. J. Org. Chem,32(12):2373-2377.
[8] Weng, J. Q.; Wang, L. and Liu, X. H. 2012. Synthesis, Crystal structure and herbicidal activity of a 1,2,4-triazol5(4H)-one derivative. J. Chem. Soc. Pakistan, 34(9):1248-1252.

[9] Liu, X. H.; Zhao, W. G.; Wang, B. L. and Li, Z. M. 2012. Synthesis, Bioactivity and DFT structureactivity relationship study of novel 1,2,3-thiadiazole derivatives. Res. Chem. Intermed,38(8):1999-2008.

[10] Marino , G. 1971. Electrophilic substitutions of five-membered rings, Adv. Heterocycl. Chem, 13: 235-314.

[11] Iddon, B. and Scrowston, R. M. 1970. Recent Advances in the Chemistry of Benzo[b]thiophenes, Adv. Heterocycl. Chem., 11:177-183.

[12] Gilchrist, T. L. 1992. Heterocyclic Chemistry, Longman publications, London, $2^{\text {nd }}$ ed, 319 .

[13] AL. Abodi, A. K.; Majed, N.; Kadhem, S. A. and Al-Bayati, R. H. 2012. Synthesis and Characterization of New 1,3-Oxazol-5-(4H)-one Derivatives, Am . J. Org. Chem, 2(6): 143-150.

[14] Turan-Zitouni, G.; Kaplancikli, Z. A.; Erol, K. and Kiliç, F. S. 1999. Synthesis and analgesic activity of some triazoles and triazolothiadiazines, Farmaco,54(4): 218-223.

[15] Pandey, V. K., Gupta, V. D., Mrinalini Upadhyay, Mridula Upadhyay, V. K. Singh and Meenal Tandon. 2005. Synthesis, characterization and Biological activity of 1,3,4-substituted 2azatidinones. Indian. J. Chem, 44B(1):158-162.

[16] Hadi , M. A. , Mohammad , L. A. and Hussein, A. A,. 2014. Preparation and Characterization of Some Transition Metal Complexes with (N, S, O) New Schiff Base Ligand, Baghdad. Science. Journal ,11(1):158-164. 
تحضيرودراسة الفعالية البايولوجية لبعض مشتقات الايميدازول الجديدة

موئيد عبود كبان*

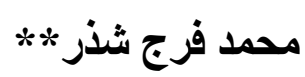

عبدالجبارخلف عطيةث٪

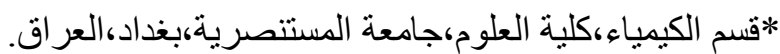
2*قشم علوم الحياة،كلية العلوم،جامعة المستتصرية،بغداد، العر اق.

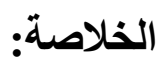

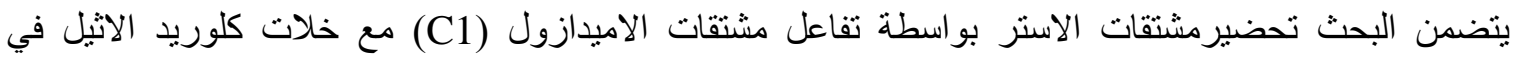

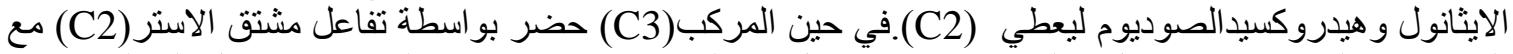

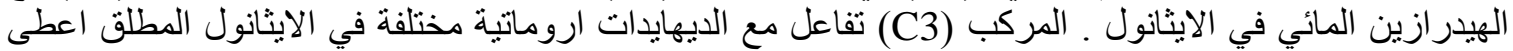

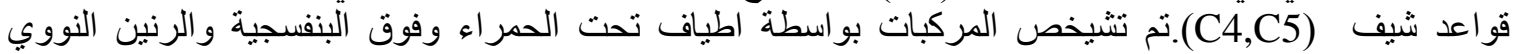

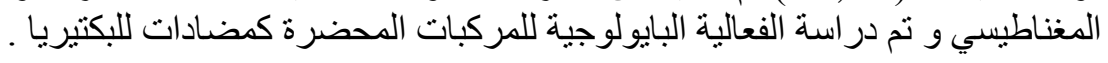

الكلمات المفتاحية: اسيتو هايدر ازايد ، قو اعد شيف ، ايميدازول 